\title{
Distribution of recent calcareous benthic foraminifera in the northern North Sea and relation to the environment
}

\author{
Dorthe Klitgaard-Kristensen, Hans Petter Sejrup \\ \& Haflidi Haflidason
}

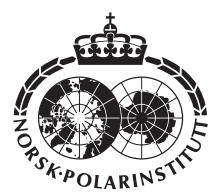

This paper compiles new and previously published data on recent calcareous benthic foraminifera (dead and living assemblages) in surface sediment samples from the northern North Sea area, focussing on the dead benthic foraminifera and their relation to the environment. Five dead benthic foraminiferal assemblages have been identified. In Scottish coastal areas Cibicides lobatulus and Rosalina sp. dominate in areas with strong current activity and coarse-grained sediments, whereas $C$. lobatulus and Trifarina angulosa dominate at similar conditions in the Norwegian coastal areas. Cassidulina laevigata assemblages occur in areas influenced by inflow of Atlantic water into the northern North Sea. In the central part of the Norwegian Channel Uvigerina mediterranea prevails in fine-grained sediments with high organic content and possibly low oxygen content. This species' restricted distribution to the Norwegian Channel could possibly be related to the availability of food. Bulimina marginata and Hyalinea balthica dominate on the Fladen Ground where seasonal stratification is pronounced. This presumably leads to a decrease in the oxygen content in the bottom-waters during part of the year.

D. Klitgaard-Kristensen, H. P. Sejrup \& H. Haflidason, Dept. of Geology, University of Bergen, Allégaten 41, N-5007 Bergen, Norway.

The aim of this study is to provide background for interpreting environmental changes in palaeorecords from the northern North Sea by investigating the distribution pattern of modern benthic calcareous foraminiferal assemblages in this region. We have compiled previous published results of recent benthic foraminifera from the northern North Sea area and combined these with foraminiferal data obtained from additional surface sediment samples in the study area (Table 1). To understand the palaeo-environment we use the relationship between the modern foraminiferal assemblage and environmental factors, such as hydrographic features and composition of the sediment, i.e. grain size, organic carbon and oxygen content of the bottom-waters.

Previous studies of foraminiferal assemblages from the entire the northern North Sea comprise those of Jarke (1961) and Gabel (1971), who identified five benthic assemblages in the northern North Sea. Murray (1991) compiled data from Jarke (1961) with his own results to describe the distribution of benthic foraminifera in the North Sea. Other studies have concentrated on more geographically restricted areas, e.g. Qvale \& van Weering (1985) in the Norwegian Channel and Sejrup et al. (1981) in the north-eastern part of the North Sea.

The study covers the region from $57^{\circ} 30^{\prime} \mathrm{N}$ to $62^{\circ} \mathrm{N}$ and $1^{\circ} \mathrm{W}$ to $6^{\circ} \mathrm{E}$ and water depths ranging from 80-500 m (Fig. 1). This region can be separated into two main areas: the Norwegian Channel and the North Sea Plateau (Fig. 1). The Norwegian Channel has water depths down to $400 \mathrm{~m}$ and is bordered by the Norwegian coastline and the western flank of the Norwegian Channel, a 


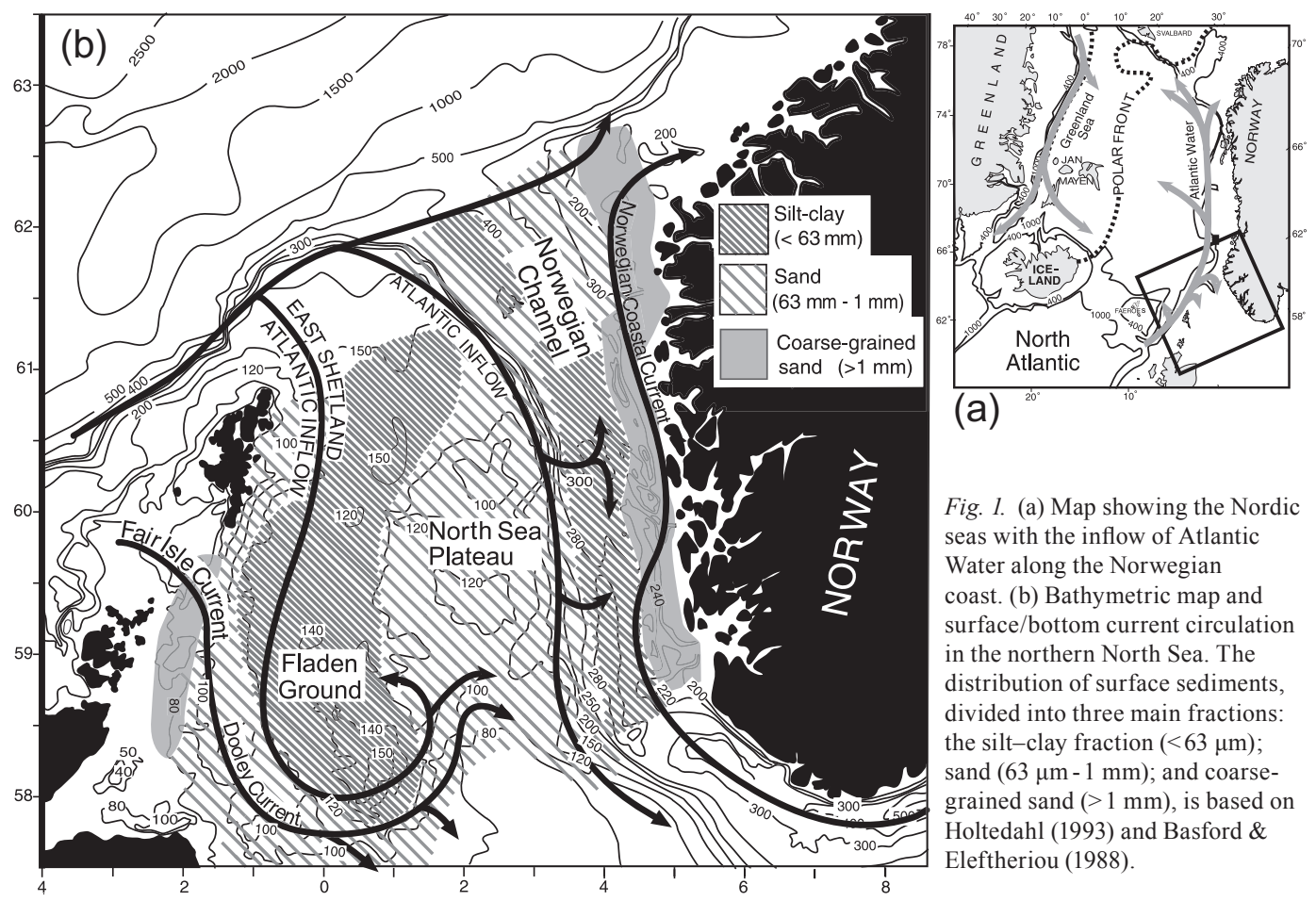

slope that outlines the transition to the North Sea Plateau. The North Sea Plateau water depths range from 100 to $150 \mathrm{~m}$. The deepest part of the North Sea Plateau is the Fladen Ground and the embayment extending north of it (Fig. 1).

The hydrography of the northern North Sea is characterized by a subsurface inflow of Atlantic Water (AW) moving southwards along the Nor-

Table 1. Sample labels (see also Table 3), number of samples, year/month samples were collected, and the investigator.

\begin{tabular}{|c|c|c|c|}
\hline $\begin{array}{l}\text { Sample } \\
\text { label }\end{array}$ & $\begin{array}{l}\text { No. of } \\
\text { samples }\end{array}$ & $\begin{array}{l}\text { Year (month) } \\
\text { collected }\end{array}$ & $\begin{array}{l}\text { Investigator or } \\
\text { published by }\end{array}$ \\
\hline AM- & 7 & 1982-83 (June/July) & Mackensen et al. 1985 \\
\hline 91- & 8 & 1991 (April) & $\begin{array}{l}\text { Klitgaard-Kristensen } \\
\text { \& Sejrup } 1996\end{array}$ \\
\hline $35-$ & 26 & 1978 (June) & Foyn 1983 \\
\hline OB- & 3 & 1983 (June) & Mackensen et al. 1985 \\
\hline$-G S$ & 9 & $\begin{array}{c}\text { 1979, 1981, } 1982 \\
\text { (May/June) }\end{array}$ & This study ${ }^{\mathrm{a}}$ \\
\hline HM-101 & 5 & 1993 (May) & This study \\
\hline HM-106 & 6 & 1995 (July) & This study \\
\hline IFM- & 5 & 1994 (July) & This study \\
\hline
\end{tabular}

a Samples provided by British Geological Survey. wegian Channel (Furnes et al. 1986) (Norwegian Channel Atlantic inflow; Fig. 1). This water enters the Skagerrak, where it mixes with other, less saline water masses from the Baltic region and the Kattegat, and returns northward along the Norwegian coast, i.e. the Norwegian Coastal Current (NCC) (NSTF 1993a; Fig. 1). The NCC forms a wedge-shaped water mass, which is well defined during winter whereas in summer large lateral extensions in surface waters are observed further west onto the North Sea Plateau (NSTF 1993a). Additional Atlantic Water inflow is found east of Shetland, flowing southwards along the Scottish coast and approximately following the $120 \mathrm{~m}$ water depth contour (Svendsen et al. 1991; NSTF 1993b). This inflow varies seasonally (Turrell et al. 1992). The AW (west) turns east at about $58^{\circ} \mathrm{N}$, and forms a gyre around the Fladen Ground (Fig. 1); it cools during winter and subsequently flows into the Skagerrak (Svendsen et al. 1991). The offshore areas in the northern North Sea are stratified in summer. A thermocline exists between 30 and $50 \mathrm{~m}$ water depth and is further enhanced by lateral excursions of the NCC above the thermocline. Strong winds reduce stratification in autumn (NSTF 1993b). 
Fig. 2. Map showing locations of samples included in this study and the main geographical areas where the five identified dead benthic foraminiferal assemblages occur. $\mathrm{SCW}=$ Scottish coastal waters; $\mathrm{FG}=$ Fladen Ground (inner and outer); $\mathrm{WF} / \mathrm{NC}=$ western flank Norwegian Channel; $\mathrm{NC}=$ Norwegian Channel; $\mathrm{NCW}=$ Norwegian coastal waters.

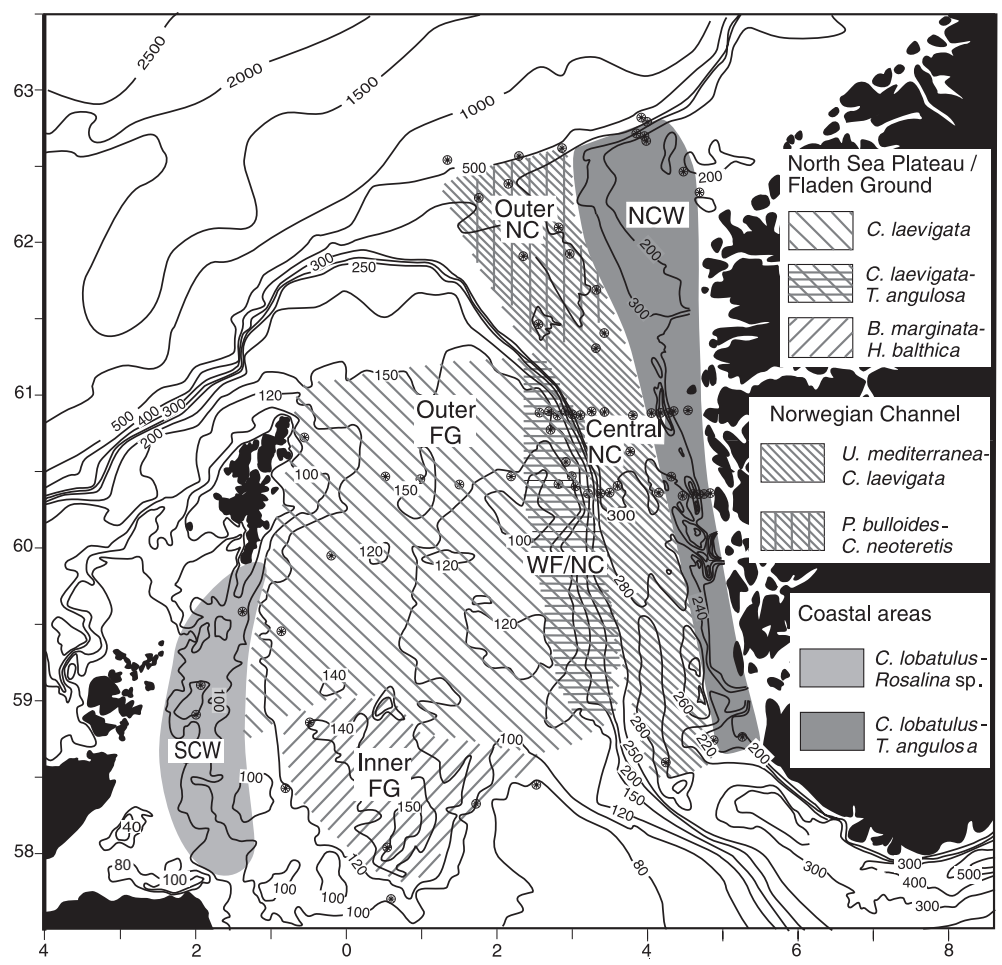

Water masses close to the Scottish coast are well mixed throughout the year because of strong tidal currents that prevent stratification in the water column. Salinity and temperature data for the different water masses are given in Table 2.

An overview of the surface sediment distribution has been compiled from previously published data (Basford \& Eleftheriou 1988; Holtedahl 1993) and based on three grain sizes: silt-clay $(<63 \mu \mathrm{m})$; fine sand $(63 \mu \mathrm{m}-1 \mathrm{~mm})$ and coarse sand $(>1 \mathrm{~mm})$ (Fig. 1). Fine-grained sediments (silt-clay) are found in the central Norwegian Channel area and in Fladen Ground (Fig. 1), where the highest amounts of organic carbon are also recorded, from 7-15 mg/g (dry sediments). The North Sea Plateau and the slope along it has a higher sand $(63 \mu \mathrm{m}-1 \mathrm{~mm})$ content (Basford \& Eleftheriou 1988) (Fig. 1). Coarse-grained material $(>1 \mathrm{~mm})$ is found close to the Scottish coast at depths shallower than $100 \mathrm{~m}$ (Basford \& Eleftheriou 1988) and along the Norwegian coast (Holtedahl 1993) where the organic content is very low (1-3 mg/g) (NSTF 1993a, 1993b).

The inflow of AW controls the oxygen content in North Sea bottom-waters. Oxygen concentrations in the Norwegian Channel area in Novem- ber to March range from 5.5 to $6.6 \mathrm{ml} / 1$ with saturation levels between $85 \%$ and $110 \%$. In the bottom-waters of the northern part of the Fladen Ground the oxygen content in the bottom-waters is around 6.2-6.8 $\mathrm{ml} / 1$ in the November-March season with saturation values varying between $100 \%$ and $110 \%$. At the inner Fladen Ground area (Fig. 2) AW is trapped during the winter and subsequent stratification during the summer leads to a situation where respiration exceeds ventilation, and oxygen levels with less than $90 \%$ saturation can be found in the bottom-waters (NSTF 1993b).

\section{Material and methods}

All samples were collected with a boxcorer. The foraminiferal content comprising dead and living (stained) specimens in the top few centimetres of surface sediments were investigated. Although carried out by a number of different investigators similar preparation techniques have been applied, mainly following Feyling-Hanssen et al. (1971) using sieve sizes of $125 \mu \mathrm{m}$ and $1.0 \mathrm{~mm}$. The samples included in this study were stained with 
Rose Bengal and the specimens were regarded living when one or more chambers were stained. In all samples 300 living (stained) and 300 dead specimens were counted from different splits. All specimens were registered. However, some samples contained fewer than 300 living (stained) individuals. In previous studies where agglutinated and calcareous benthic foraminifera have been counted together the agglutinated has been excluded from the data (e.g. Mackensen et al. 1985). This approach is chosen simply because in the majority of Quaternary stratigraphic records the resulting assemblage is composed entirely of calcareous foraminifera since agglutinated individuals often disintegrate easily after death. Hence, the composition of the modern calcareous assemblage is more applicable in Holocene stratigraphic marine records.

A total of 69 samples are included in this study and their locations are shown in Fig. 2 (see also Table 3). The percentages data for living (stained) and dead benthic foraminifera mentioned in the text are available from the author upon request. For the living species only 64 samples were studied.

The method of sampling only the top few centimetres has been critized (e.g. Jorissen et al. 1995) because it may lead to loss of infaunal species and individuals, affecting the composition and the determination of density of foraminifera. Several studies have shown that live foraminifera can occur at least $8 \mathrm{~cm}$ down in the sediment (e.g. Corliss \& van Weering 1993). However, the majority of species and individuals (on average $70 \%$ or more) occur within the uppermost $2 \mathrm{~cm}$ (van der Zwaan et al. 1999). Therefore, the upper $2 \mathrm{~cm}$ is regarded as sufficient to obtain a representative general distribution of the present fauna in the northern North Sea area.
The environmental parameters shown in Table 2 are either average numbers or a range of the environmental parameter in each of the main areas in the northern North Sea. The sampling of the material included in this study has been carried out over more than 20 years and in most studies the information on the environmental setting obtained is limited. It has been necessary to rely on additional environmental data from other studies in the North Sea. Hence only a broader relationship between the foraminiferal fauna and the environment can be established.

\section{Results and discussion}

The establishment of the foraminiferal assemblages in the northern North Sea are based on the occurrence (in percent) of the most dominating species and other species that characterize the assemblage in certain geographical areas. The main purpose of including the living foraminifera in this study was to compare their occurrences with the dead benthic foraminifera in order to detect reworked specimens and to investigate how well the dead assemblage reflects the living assemblage. Although the number of living specimens is generally low, five main living assemblages were recognized in the following areas: (1) Scottish coastal waters; (2) Norwegian coastal waters; (3) inner and outer Fladen Ground; (4) western flank of the Norwegian Channel; (5) and an outer and central Norwegian Channel fauna. The overall distribution pattern of the main five assemblages of the living and dead foraminifera for the North Sea display similarities implying that the dead fauna reflects modern conditions. However, the occurrences of the species $C$. reniforme and E. excavatum

Table 2. Physical parameters from the different areas in the northern North Sea. Based on NSTF (1993a, 1993b, 1993c, 1993d). Salinity, temperature and oxygen content refer to bottom-water.

\begin{tabular}{|c|c|c|c|c|c|c|}
\hline & \multicolumn{3}{|c|}{ Norwegian Channel } & \multicolumn{2}{|c|}{ Fladen Ground } & \multirow{2}{*}{$\begin{array}{c}\text { Scottish } \\
\text { coast }\end{array}$} \\
\hline & central $\mathrm{I}$ & North Sea Plateau & Norw. coast & central & outer & \\
\hline Salinity & $35.0-35.4$ & $35.0-35.4$ & $30-34.9$ & 35.1 & $34.9-35.3$ & 35.0 \\
\hline Temperature $\left({ }^{\circ} \mathrm{C}\right)$ & $7.5-9.0$ & $7.5-9.0$ & $3-18$ & $7-9.5$ & $6-9.5$ & $8-10$ \\
\hline Current speed $(\mathrm{cm} / \mathrm{s})$ & low & $5-15$ & $10-20$ & low & no data & 50 \\
\hline$\%$ silt-clay content & $50-90$ & $<10$ & $<50$ & $>90 \%$ & $10-30$ & $<2$ \\
\hline Carbon $(\mathrm{mg} / \mathrm{g})$ & $10-15$ & $1-3$ & $<5$ & $7-10$ & $3-7$ & $1-3$ \\
\hline $\begin{array}{l}\text { Oxygen }(\mathrm{ml} / 1 \\
\text { or saturat) }\end{array}$ & $\begin{array}{c}5.5-6.6 \mathrm{ml} / 1 \\
85-110 \%\end{array}$ & no data & $\begin{array}{c}5.5-6.6 \mathrm{ml} / 1 \\
85-110 \%\end{array}$ & sat. $90 \%$ & $\begin{array}{c}6.2-6.8 \mathrm{ml} / 1 \\
100-110 \%\end{array}$ & no data \\
\hline
\end{tabular}


are observed only in the dead fauna. Based on this and that these species normally occur in glacial deposits, they are regarded as reworked, corroborating previous findings in the northern North Sea (Sejrup et al. 1981).

(1) In the Scottish coastal waters at depths shallower than $100 \mathrm{~m}$, the assemblage is dominated by $C$. lobatulus (56-63\%) with Rosalina sp. (4-17\%) and Cibicides refulgens (1-18\%) as associated species (Fig. 2). This assemblage along the Scottish coast is found in sediments composed of coarse-grained sand (biogenic sands) with less than $2 \%$ silt-clay content and very low organic carbon content (1-3 mg/g; Table 2). The area is influenced by the FIC (Fig. 1), a mixture of Scottish coastal waters and Atlantic Water, and is subject to wave and strong tidal activity (current speed up to $50 \mathrm{~cm} / \mathrm{s}$; Table 2). C. lobatulus thriving in this high energy environment corroborates previous studies where $C$. lobatulus was found in bottom environments characterized by high current activity and sandy sediments (e.g. Sejrup et al. 1981; Murray 1991; Conradsen 1993). Furthermore, as previously found by Murray (1985), C. lobatulus and Rosalina sp. live attached to hydroids in the Fair Isle Channel, making the species suitable for the turbulent environments of Scottish coastal waters.

(2) The Norwegian coastal waters are distinguished by a fauna consisting of $T$. angulosa (31-8\%) and C. lobatulus (4-42\%) that dominate water depths shallower than $400 \mathrm{~m}$ out to the shelf edge at $63^{\circ} \mathrm{N}$ (Fig. 2). Associated species are C. obtusa $(1-13 \%)$ and $C$. refulgens $(2-12 \%)$. This assemblage occurs in bottom environment that is characterized by coarsegrained sediments, relatively high current speeds $(10-20 \mathrm{~cm} / \mathrm{s})$ and low amount of organic carbon (Table 2). Mackensen et al. (1985) found that $C$. lobatulus, C. refulgens and C. obtusa showed a strong correlation to coarse-grained sediments whereas $T$. angulosa has been related to low organic content in the Norwegian Channel (Qvale \& van Weering 1985). These previous findings and relationships are in agreement with the occurrence of the fauna in this study. However, the Norwegian coastal fauna is slightly different from the Scottish due to its higher frequency of T. angulosa. The reason for this difference is not clear but the most striking environmental factor is the current speed (Table 2), which is lower along the Norwegian coast compared to the Scottish coast.
(3) In the Fladen Ground area, B. marginata (26-41\%), C. laevigata $(7-41 \%)$ and $H$. balthica (11-24\%) are frequent (Fig. 2). The northern part of the Fladen Ground is dominated by $C$. laevigata (49-72\%) together with $B$. marginata (0.5-19\%). The dominating species in the southern part of the Fladen Ground are $B$. marginata and $H$. balthica. This area is characterized by fine grained sediment (silt-clay content $90 \%$ ) accumulation with relatively high content of organic carbon (7-10 mg/g) compared with other areas in the North Sea (NSTF 1993b). The southern part of the Fladen Ground is occupied by cooled Atlantic Water that is trapped during the summer. At this time respiration exceeds ventilation in bottom-water masses, leading to a decrease in oxygen saturation (NSTF 1993b). The species B. marginata and H. balthica seem to flourish in these stratified water masses, which are associated with decreasing oxygen content in the sediments. These results accord with a study in the Kattegat where $B$. marginata was recorded in association with seasonally changing hydrographic conditions and finegrained and organic-rich substrates (Conradsen et al. 1994). In laboratory experiments Alve \& Bernhard (1995) have shown that B. marginata increased in frequency during lowered oxygen levels in the sediments. In the Gulf of Mexico $H$. balthica was found at greater water depths (600-1000 m) but coinciding with lowered oxygen content in the water masses (Gupta Sen \& Machain-Castillo 1993). Furthermore, Qvale \& van Weering (1985) found a positive correlation of $H$. balthica with organic carbon content in the Skagerrak. In this study the high organic content and the fine-grained sediments appear to be of secondary importance because the occurrences of B. marginata and $H$. balthica are modest in the Norwegian Channel, where environmental conditions are comparable to the Fladen Ground (see Table 2). Instead, the two species seem to thrive where stratification is pronounced and where the oxygen content changes in the sediments throughout the year.

(4) Along the Norwegian Channel's western flank (Fig. 2), at depths shallower than $200 \mathrm{~m}$, the assemblage is dominated by $C$. laevigata (49-89\%), co-occurring with $T$. angulosa $(6-27 \%)$ and a scattered distribution of $C$. lobatulus $(1-15 \%)$ and $C$. obtusa (3-9\%). The two $C$. laevigata assemblages along the western flank of the Norwegian Channel and in the outer part of the 
Table 3. List of samples and geographic coordinates and the geographical area in which they are located. (Table continues next column.)

\begin{tabular}{|c|c|c|c|}
\hline Area & Sample no. & Latitude & Longitude \\
\hline \multicolumn{4}{|c|}{ Outer Norwegian Channel } \\
\hline & AM149 & $62^{\circ} 41 .^{\prime} \mathrm{N}$ & $03^{\circ} 53.6^{\prime} \mathrm{E}$ \\
\hline & AM125 & $62^{\circ} 45.1^{\prime} \mathrm{N}$ & $03^{\circ} 56.9^{\prime} \mathrm{E}$ \\
\hline & AM148 & $62^{\circ} 43.1^{\prime} \mathrm{N}$ & $03^{\circ} 48.9^{\prime} \mathrm{E}$ \\
\hline & HM101-1 & $62^{\circ} 37.40^{\prime} \mathrm{N}$ & $02^{\circ} 43.86^{\prime} \mathrm{E}$ \\
\hline & HM101-2 & $62^{\circ} 34.89^{\prime} \mathrm{N}$ & $02^{\circ} 19.98^{\prime} \mathrm{E}$ \\
\hline & HM101-3 & $62^{\circ} 25.00^{\prime} \mathrm{N}$ & $02^{\circ} 04.00^{\prime} \mathrm{E}$ \\
\hline & HM101-4 & $62^{\circ} 18.15^{\prime} \mathrm{N}$ & $01^{\circ} 42.50^{\prime} \mathrm{E}$ \\
\hline & AM103 & $62^{\circ} 07.4^{\prime} \mathrm{N}$ & $02^{\circ} 43.2^{\prime} \mathrm{E}$ \\
\hline & HM106-2 & $61^{\circ} 17.01^{\prime} \mathrm{N}$ & $03^{\circ} 18.00^{\prime} \mathrm{E}$ \\
\hline & HM106-3 & $61^{\circ} 30.06^{\prime} \mathrm{N}$ & $03^{\circ} 29.94^{\prime} \mathrm{E}$ \\
\hline & HM106-4 & $61^{\circ} 29.98^{\prime} \mathrm{N}$ & $02^{\circ} 29.71^{\prime} \mathrm{E}$ \\
\hline & HM106-5 & $61^{\circ} 46.15^{\prime} \mathrm{N}$ & $03^{\circ} 17.89^{\prime} \mathrm{E}$ \\
\hline & HM106-6 & $61^{\circ} 53.06^{\prime} \mathrm{N}$ & $02^{\circ} 54.04^{\prime} \mathrm{E}$ \\
\hline & HM106-7 & $61^{\circ} 59.04^{\prime} \mathrm{N}$ & $02^{\circ} 20.03^{\prime} \mathrm{E}$ \\
\hline \multicolumn{4}{|c|}{ Central Norwegian Channel } \\
\hline & $35-10$ & $60^{\circ} 54.0^{\prime} \mathrm{N}$ & $04^{\circ} 14.3^{\prime} \mathrm{E}$ \\
\hline & $35-11$ & $60^{\circ} 54.0^{\prime} \mathrm{N}$ & $04^{\circ} 01.6^{\prime} \mathrm{E}$ \\
\hline & $35-12$ & $60^{\circ} 53.4^{\prime} \mathrm{N}$ & $03^{\circ} 49.3^{\prime} \mathrm{E}$ \\
\hline & $35-14$ & $60^{\circ} 54.4^{\prime} \mathrm{N}$ & $03^{\circ} 25.3^{\prime} \mathrm{E}$ \\
\hline & $35-15$ & $60^{\circ} 54.3^{\prime} \mathrm{N}$ & $03^{\circ} 13.0^{\prime} \mathrm{E}$ \\
\hline & $35-16$ & $60^{\circ} 53.2^{\prime} \mathrm{N}$ & $03^{\circ} 06.5^{\prime} \mathrm{E}$ \\
\hline & $35-17$ & $60^{\circ} 53.8^{\prime} \mathrm{N}$ & $03^{\circ} 00.8^{\prime} \mathrm{E}$ \\
\hline & $35-18$ & $60^{\circ} 54.0^{\prime} \mathrm{N}$ & $02^{\circ} 55.0^{\prime} \mathrm{E}$ \\
\hline & $35-27$ & $60^{\circ} 21.5^{\prime} \mathrm{N}$ & $03^{\circ} 22.5^{\prime} \mathrm{E}$ \\
\hline & $35-28$ & $60^{\circ} 22.3^{\prime} \mathrm{N}$ & $03^{\circ} 30.5^{\prime} \mathrm{E}$ \\
\hline & $35-30$ & $60^{\circ} 22.5^{\prime} \mathrm{N}$ & $04^{\circ} 10.5^{\prime} \mathrm{E}$ \\
\hline & $35-31$ & $60^{\circ} 22.5^{\prime} \mathrm{N}$ & $04^{\circ} 30.0^{\prime} \mathrm{E}$ \\
\hline & IFM-94-2 & $60^{\circ} 24.97^{\prime} \mathrm{N}$ & $03^{\circ} 36.05^{\prime} \mathrm{E}$ \\
\hline & $91-1$ & $60^{\circ} 38.02^{\prime} \mathrm{N}$ & $03^{\circ} 43.26^{\prime} \mathrm{E}$ \\
\hline & $91-11$ & $58^{\circ} 41.48^{\prime} \mathrm{N}$ & $04^{\circ} 13.89^{\prime} \mathrm{E}$ \\
\hline & $91-12$ & $58^{\circ} 45.48^{\prime} \mathrm{N}$ & $04^{\circ} 51.03^{\prime} \mathrm{E}$ \\
\hline \multicolumn{4}{|c|}{ Western flank Norwegian Channel } \\
\hline & IFM-94-3 & $60^{\circ} 24.97^{\prime} \mathrm{N}$ & $02^{\circ} 09.95^{\prime} \mathrm{E}$ \\
\hline & $35-19$ & $60^{\circ} 53.5^{\prime} \mathrm{N}$ & $02^{\circ} 48.0^{\prime} \mathrm{E}$ \\
\hline & $35-20$ & $60^{\circ} 54.0^{\prime} \mathrm{N}$ & $02^{\circ} 42.0^{\prime} \mathrm{E}$ \\
\hline & $35-21$ & $60^{\circ} 54.0^{\prime} \mathrm{N}$ & $02^{\circ} 35.0^{\prime} \mathrm{E}$ \\
\hline & $35-22$ & $60^{\circ} 46.3^{\prime} \mathrm{N}$ & $02^{\circ} 43.2^{\prime} \mathrm{E}$ \\
\hline & $35-24$ & $60^{\circ} 30.5^{\prime} \mathrm{N}$ & $02^{\circ} 57.5^{\prime} \mathrm{E}$ \\
\hline & $35-26$ & $60^{\circ} 22.4^{\prime} \mathrm{N}$ & $03^{\circ} 14.0^{\prime} \mathrm{E}$ \\
\hline & OB-10 & $60^{\circ} 31.7^{\prime} \mathrm{N}$ & $02^{\circ} 54.8^{\prime} \mathrm{E}$ \\
\hline & OB-16 & $60^{\circ} 26.7^{\prime} \mathrm{N}$ & $02^{\circ} 45.3^{\prime} \mathrm{E}$ \\
\hline & OB-18 & $60^{\circ} 28.4^{\prime} \mathrm{N}$ & $02^{\circ} 54.7^{\prime} \mathrm{E}$ \\
\hline \multicolumn{4}{|c|}{ Outer Fladen Ground } \\
\hline & IFM-94-4 & $60^{\circ} 24.95^{\prime} \mathrm{N}$ & $01^{\circ} 30.04^{\prime} \mathrm{E}$ \\
\hline & IFM-94-5 & $60^{\circ} 27.98^{\prime} \mathrm{N}$ & $00^{\circ} 59.70^{\prime} \mathrm{E}$ \\
\hline & 59-01/105GS & $59^{\circ} 27.7^{\prime} \mathrm{N}$ & $00^{\circ} 52.1 \mathrm{~W}$ \\
\hline & 59-01/40GS & $59^{\circ} 54.75^{\prime} \mathrm{N}$ & $00^{\circ} 10.6^{\prime} \mathrm{W}$ \\
\hline & $60-00 / 271 \mathrm{GS}$ & $60^{\circ} 25.8^{\prime} \mathrm{N}$ & $00^{\circ} 30.25^{\prime} \mathrm{E}$ \\
\hline & 60-00/259GS & $60^{\circ} 43.8^{\prime} \mathrm{N}$ & $00^{\circ} 34.0^{\prime} \mathrm{W}$ \\
\hline \multicolumn{4}{|c|}{ Inner Fladen Ground } \\
\hline & $91-9$ & $58^{\circ} 28.93^{\prime} \mathrm{N}$ & $02^{\circ} 28.26^{\prime} \mathrm{E}$ \\
\hline & $91-5$ & $57^{\circ} 44.06^{\prime} \mathrm{N}$ & $00^{\circ} 36.49^{\prime} \mathrm{E}$ \\
\hline & $91-8$ & $58^{\circ} 23.80^{\prime} \mathrm{N}$ & $01^{\circ} 43.98^{\prime} \mathrm{E}$ \\
\hline & $91-6$ & $58^{\circ} 04.01^{\prime} \mathrm{N}$ & $00^{\circ} 33.01^{\prime} \mathrm{E}$ \\
\hline & $58-01 / 332 \mathrm{GS}$ & $58^{\circ} 27.8^{\prime} \mathrm{N}$ & $00^{\circ} 48.0^{\prime} \mathrm{W}$ \\
\hline & 58-01/190GS & $58^{\circ} 54.0^{\prime} \mathrm{N}$ & $00^{\circ} 29.8^{\prime} \mathrm{W}$ \\
\hline
\end{tabular}

Fladen Ground are both located under the main inflow routes of Atlantic Water into the northern North Sea (Fig. 1). This suggests that $C$. laevigata prefers areas in the North Sea where the incoming water is of more oceanic origin. Our finding of $C$. laevigata dominating in waters of oceanic origin and avoiding areas of fine-grained sediments (i.e. central Norwegian Channel and Fladen Ground) suggests that it thrives in more turbulent environments and probably in well oxygenated waters. Bergsten et al. (1996) identified four assemblages in the Skagerrak of which two were dominated by $C$. laevigata. The $C$. laevigata assemblages occurred on the northern and the southern flank of the Skagerrak. However, the highest dominance of $C$. laevigata was recorded in water masses originating from the inflow of Atlantic Water through the Norwegian Channel, whereas the frequency of $C$. laevigata was lower in water masses with a residence time of 100 days (Bergsten et al. 1996). Other studies in the Skagerrak found a $C$. laevigata assemblage in a transition zone between stable bottom-waters and mixed upper waters, hence under turbulent bottom conditions (Qvale \& van Weering 1985; Conradsen et al. 1994). Based on these findings we suggest that $C$. laevigata generally avoids areas of lowered oxygen content; for the North Sea this is where the inflow of Atlantic Water occurs.

In the central part of the Norwegian Channel (Fig. 2), the fauna is dominated by $U$. mediterranea (6-44\%) and C. laevigata (14-40\%). However, the highest occurrences of $C$. laevigata

\begin{tabular}{|c|c|c|c|}
\hline Area & Sample no. & Latitude & Longitude \\
\hline \multicolumn{4}{|c|}{ Norwegian coastal waters } \\
\hline & $91-13$ & $58^{\circ} 47.98^{\prime} \mathrm{N}$ & $05^{\circ} 16.16^{\prime} \mathrm{E}$ \\
\hline & $35-6$ & $60^{\circ} 54.0^{\prime} \mathrm{N}$ & $04^{\circ} 31.5^{\prime} \mathrm{E}$ \\
\hline & $35-7$ & $60^{\circ} 54.0^{\prime} \mathrm{N}$ & $04^{\circ} 26.6^{\prime} \mathrm{E}$ \\
\hline & $35-9$ & $60^{\circ} 54.0^{\prime} \mathrm{N}$ & $04^{\circ} 16.5^{\prime} \mathrm{E}$ \\
\hline & $35-32$ & $60^{\circ} 22.6^{\prime} \mathrm{N}$ & $04^{\circ} 38.0^{\prime} \mathrm{E}$ \\
\hline & $35-33$ & $60^{\circ} 22.5^{\prime} \mathrm{N}$ & $04^{\circ} 43.5^{\prime} \mathrm{E}$ \\
\hline & $35-34$ & $60^{\circ} 22.6^{\prime} \mathrm{N}$ & $04^{\circ} 47.0^{\prime} \mathrm{E}$ \\
\hline & $35-35$ & $60^{\circ} 22.5^{\prime} \mathrm{N}$ & $04^{\circ} 50.5^{\prime} \mathrm{E}$ \\
\hline & $35-36$ & $60^{\circ} 22.5^{\prime} \mathrm{N}$ & $04^{\circ} 53.3^{\prime} \mathrm{E}$ \\
\hline & AM152 & $62^{\circ} 18.3^{\prime} \mathrm{N}$ & $04^{\circ} 39.6^{\prime} \mathrm{E}$ \\
\hline & AM126 & $62^{\circ} 28.3^{\prime} \mathrm{N}$ & $04^{\circ} 27.3^{\prime} \mathrm{E}$ \\
\hline & AM151 & $62^{\circ} 38 .^{\prime} \mathrm{N}$ & $04^{\circ} 00.2^{\prime} \mathrm{E}$ \\
\hline & AM150 & $62^{\circ} 39^{\prime} \mathrm{N}$ & $03^{\circ} 59.1^{\prime} \mathrm{E}$ \\
\hline \multicolumn{4}{|c|}{ Scottish coastal waters } \\
\hline & 59-02/124GS & $59^{\circ} 35.7^{\prime} \mathrm{N}$ & $01^{\circ} 22.5^{\prime} \mathrm{W}$ \\
\hline & 59-02/187GS & $59^{\circ} 06.81^{\prime} \mathrm{N}$ & $01^{\circ} 55.6^{\prime} \mathrm{W}$ \\
\hline & $58-02 / 121 \mathrm{GS}$ & $58^{\circ} 56.3^{\prime} \mathrm{N}$ & $01^{\circ} 58.8^{\prime} \mathrm{W}$ \\
\hline
\end{tabular}


are found at the slope of the western flank. Other species associated with the central Norwegian Channel are $M$. barleeanus $(2-10 \%)$ and $B$. marginata (2-10\%). Sporadic occurrences of Bolivina skagerrakensis (four samples with frequencies between $14-31 \%$ ) are found in the central part of the Norwegian Channel. The species $U$. mediterranea dominates in the central part of the Norwegian Channel where sediments are very fine-grained (up to $90 \%$ silt-clay), indicating that this species prefers fine-grained sediments and high organic carbon content. If substrate were a controlling factor for this species it would be expected to occur at the inner Fladen Ground where sediments are fine-grained (up to $90 \%$ silt-clay) but only a low percentage of $U$. mediterranea $(1-3 \%)$ are recorded. Other differences between the two areas are seasonal stratification and higher variability in the inflow of Atlantic Water into the Fladen Ground than in the Norwegian Channel, which affects the availability of nutrients and oxygen content (Svendsen et al. 1991). It is therefore possible that the food (amount and/or quality) and oxygen content are other important factors for the dominance of $U$. mediterranea. A study of benthic foraminifera along a transect from the Norwegian Channel and into western Norwegian fjords showed that $U$. mediterranea avoided the fjords where the quality of the organic matter decreased based on $\mathrm{C} / \mathrm{N}$ ratios (KlitgaardKristensen \& Buhl-Mortensen 1999). In the Adriatic Sea, de Stigter et al. (1998) found that $U$. mediterranea was a superior competitor in foodand oxygen-rich environments but the species decreased in frequency in environments with less food and oxygen. This may also apply for the North Sea where $U$. mediterranea is less frequent in areas with strong stratification, lowered oxygen content in the sediment and less food availability. Instead other species such as B. marginata and $H$. balthica tend to dominate. Quantified data on the amount and quality of food in the North Sea are, however, more difficult to access. In studies of organic matter (sources and burial) in the Norwegian Channel it was found that the amount of organic carbon was $1.7 \times 10^{5}$ tonne/yr and that less than $10 \%$ originated from primary productivity (de Haas \& van Weering 1997; de Haas et al. 1997). On the North Sea Plateau the estimate was $1 \times 10^{5}$ tonne/yr with $0.14 \%$ contributing to the primary productivity (de Haas \& van Weering 1997; de Haas et al. 1997). These numbers indicate that food may be excessive in the Norwegian Channel compared to other parts of the North Sea but it is still speculative if this is the main reason for the observed distribution pattern in the foraminifera.

The outer part of the Norwegian Channel (north of $61^{\circ} 30^{\prime} \mathrm{N}$ ) (Fig. 2) shows similarities with the central part, but, in addition, $C$. neoteretis (1-28\%) and P. bulloides (2-7\%) also occur in this area. This could reflect a decrease in temperature at the outer part of the Norwegian Channel as compared to the more central parts.

The distribution of the assemblages in this study is generally in agreement with the previously published distribution maps for the North Sea (Jarke 1961; Qvale \& van Weering 1985). However, along the Norwegian coast we have identified an additional $T$. angulosa assemblage, which has not been shown in previous papers. Jarke (1961) defined an assemblage in the Fladen Ground area, which was characterized by $H$. balthica, B. marginata and Stainforthia fusiformis (as Bulimina fusiformis). This is in accordance with these findings, although it has only been possible to document a scattered occurrence of the smallsized $S$. fusiformis. This is presumably due to the use of different sieve sizes in the studies.

\section{Conclusions}

Five assemblages have been identified in a compilation of new and previously published data on the distribution of the dead foraminiferal calcareous benthic foraminifera in the northern North Sea area. The extended knowledge of the relationship between foraminiferal assemblages and the bottom environment in the northern North Sea obtained in this study will help us improve future palaeoceanographic and palaeoenvironmental interpretations of palaeo-records from this area.

\footnotetext{
Acknowledgements.-This study is a contribution to the European MAST III programme through the European North Atlantic Margin (ENAM II) research project. The British Geological Survey placed samples at our disposal. Rune Foyn provided us with useful data from the Norwegian Channel. The crew of RV Håkon Mosby assisted during the cruises in the North Sea. Else Lier made some of the illustrations. To all these institutions and persons we offer our sincere thanks. We also thank the reviewers for valuable and thoughtful comments and ideas.
} 


\section{References}

Alve, E. \& Bernhard, J. 1995: Vertical migratory response of benthic foraminifera to controlled oxygen concentrations in an experimental mesocosm. Mar. Ecol. Prog. 116, 137151.

Basford, D. \& Eleftheriou, A. 1988: The benthic environment of the North Sea $\left(56-61^{\circ} \mathrm{N}\right)$. J. Mar. Biol. Ass. UK 68, 125-141.

Bergsten, H., Nordberg, K. \& Malmgren, B. 1996: Recent benthic foraminifera as tracers of water masses along a transect in the Skagerrak, north-eastern North Sea. J. Sea Res. 35, 111-121.

Conradsen, K. 1993: Recent benthic foraminifera in the southern Kattegat, Scandinavia: distributional pattern and controlling parameters. Boreas 22, 367-382.

Conradsen, K., Bergsten, H., Knudsen, K. L., Nordberg, K. \& Seidenkrantz, M.-S. 1994: Recent benthic foraminiferal distribution in the Kattegat and Skagerrak, Scandinavia. In H. P. Sejrup \& K. L. Knudsen (eds.): Late Ceonozoic benthic foraminifera: taxonomy, ecology and stratigraphy. Cushman Found. Spec. Publ. 32. Pp. 53-68. Washington D.C.: Cushman Foundation for Foraminiferal Research.

Corliss, B. H. \& van Weering, T. C. E. 1993: Living (stained) benthic foraminifera within surficial sediments of the Skagerrak. Mar. Geol. 11, 323-335.

de Haas, H. \& van Weering, T. C. E. 1997: Recent sedimentation, organic carbon burial and transport in the northeastern North Sea. Mar. Geol. 136, 173-187.

de Haas, H., Boer, W. \& van Weering, T. C. E. 1997: Recent sedimentation and organic carbon burial in a shelf sea; the North Sea. Mar. Geol. 144, 131-146.

de Stigter, H. C., Jorissen, F. J. \& van der Zwaan, G. J. 1998: Bathymetric distribution and microhabitat partitioning of live (Rose Bengal stained) benthic foraminifera along a shelf to bathyal transect in the southern Adriatic Sea. $J$. Foraminifer. Res. 28, 40-57.

Feyling-Hanssen, R., Jørgensen, J. A., Knudsen, K. L. \& Lykke Andersen, A.-L. 1971: Late Quaternary foraminifera from Vendsyssel, Denmark and Sandnes, Norway. Bull. Geol. Soc. Den. 21, 67-317.

Foyn, R. 1983: Resent benthonisk foraminifer-og sediment utbredelse $i$ Nordsjøen, vest for Hordaland og Sogn. (Recent benthic foraminfera and sediment distribution in the North Sea, west of Hordaland and Sogn.) Master's thesis, University of Bergen.

Furnes, G. K., Hackett, B. \& Sætre, R. 1986: Retroflection of Atlantic water in the Norwegian Trench. Deep-Sea Res. 33, 247-265.

Gabel, B. 1971: Die foraminiferen der Nord See. Helgol. Wiss. Meeresunters. 22, 1-65.

Gupta Sen, B. K. \& Machain-Castillo, M. L. 1993: Benthic foraminifera in oxygen-poor habitats. Mar. Micropaleontol. 20, 183-201.

Holtedahl, H. 1993: Marine geology of the Norwegian continental margin. Nor. Geol. Unders. Spec. Publ. 6, 1-150.

Jarke, J. 1961: Die Beziehung zwischen hydrographischen
Verhältnissen, Faziesentwicklung und Foraminiferenverbreitung in der heutigen Nordsee als Vorbild Für die Verhältnisse während der Miocän-zeit. (The relationship between hydrographic conditions, facies development and foraminiferal distribution at present in the North Sea as an example of Miocene conditions.) Meyniana 10, 21-36.

Jorissen, F. J., de Stigter, H. C. \& Widmark, J. G. V. 1995: A conceptual model explaining benthic foraminiferal microhabitats. Mar. Micropaleontol. 26, 3-15.

Klitgaard-Kristensen, D. \& Buhl-Mortensen, L. 1999: Benthic foraminifera along an offshore-fjord gradient: a comparison with amphipods and molluscs. J. Nat. Hist. 33, 317-350.

Klitgaard-Kristensen, D. \& Sejrup, H. P. 1996: Modern benthic foraminiferal biofacies across the northern North Sea. Sarsia 81, 97-106.

Mackensen, A. 1985: Verbreitung und umwelt benthischer foraminiferen in der Norwegischen See. (Distribution and associated environment of benthic foraminifera in the Norwegian Sea.) $\mathrm{PhD}$ dissertation, Christian-Albrechts University, Kiel

Mackensen, A., Sejrup, H. P. \& Jansen, E. 1985: The distribution of living foraminifera on the continental slope and rise off southwest Norway. Mar. Micropaleontol. 9, 275-306.

Murray, J. W. 1985: Recent Foraminifera from the North Sea (Forties and Ekofisk areas) and the continental shelf west of Scotland. J. Micropaleontol. 4, 117-125.

Murray, J. W. 1991: Ecology and palaeoecology of benthic foraminifera. Harlow: Longman.

NSTF (North Sea Task Force) 1993a: North Sea subregion 6 assessment report. State Pollution Control Authority, Norway, Oslo.

NSTF (North Sea Task Force) 1993b: North Sea subregion $2 b$ assessment report. The Scottish Office (Agriculture and Fisheries Department) Marine Laboratory, Torry, UK.

NSTF (North Sea Task Force) 1993c: North Sea subregion 1 assessment report. State Pollution Control Authority, Oslo, Norway.

NSTF (North Sea Task Force) 1993d: North Sea subregion 7 a assessment report. Federal Maritime and Hydrographic Agency of Germany, Hamburg.

Qvale, G. \& van Weering, T. J. E. 1985: Relationship of surface sediments and benthic foraminiferal distribution patterns in the Norwegian Channel (northern North Sea). Mar. Micropaleontol. 9, 469-488.

Sejrup, H. P., Fjæran, T., Hald., M., Beck., L., Hagen, J., Miljeteig, I., Morvik, I. \& Norvik, O. 1981: Benthonic foraminifera in surface samples from the Norwegian continental margin between $62^{\circ} \mathrm{N}$ and $65^{\circ} \mathrm{N}$. J. Foraminifer. Res. 11, 277-295.

Svendsen, E., Sætre, R. \& Mork, M. 1991: Features of the northern North Sea circulation. Cont. Shelf Res. 11, 493-508.

Turrell, W. R., Henderson, E. W., Slesser, G., Payne, R. \& Adams, R. D. 1992: Seasonal changes in the circulation of the northern North Sea. Cont. Shelf Res. 12, 257-286.

van der Zwaan, G. J., DuijnsteeI, A. P., den Dulk, M., Ernst, S. R., Jannink, N. T. \& Kouwenhoven, T. J. 1999: Benthic foraminifers: proxies or problems? A review of paleoecological concepts. Earth Sci. Rev. 46, 213-236. 